\title{
Value of Vitamin D Administration Versus Suppressing Gut Microbiota in Modifying Metabolic Associated Osteoarthritis in Rats
}

\author{
RANDA S. GOMAA, M.D.*; JEHAN SAEED, M.D.** and SAFYA E. ESMAEEL, M.D.* \\ The Departments of Medical Physiology* and Internal Medicine**, Faculty of Medicine, Zagazig University
}

\begin{abstract}
Background: Metabolic syndrome (MetS) is considered as common risk factors for knee osteoarthritis (OA).

Aim of Study: Comparing the effect of vit. D supplementation and gut microbiota suppression on the development of metabolic knee OA in rats is the aim of the study.

Material and Methods: Forty adult male rats were subdivided into control and high carbohydrate high fat (HCHF) fed rats that furtherly subdivided into: HCHF (positive control), HCHF-Vitamin D treated \& HCHF-antibiotics treated. Body mass index (BMI), serum glucose, insulin, total cholesterol, triglycerides, HDL-C, LDL-C, inflammatory cytokines were estimated. Homeostatic model assessment for insulin resistance (HOMA-IR) was calculated. Synovial cytokine, tissue degenerative enzymes gene expression and knee histopathology were assessed.

Results: HCHF induced significant increase in BMI, glucose, insulin, HOMA-IR, serum and synovial cytokines and degenerative enzymes with dyslipidemia and knee joint damage compared with controls. Vit. D improved all parameters in comparison to HCHF fed group. Antibiotic administration improved glucose, insulin, HOMA-IR, dyslipidemia and serum cytokines but induced insignificant changes in BMI, synovial cytokines, degenerative enzymes and knee joint damage compared with HCHF fed group.

Conclusion: HCHF diet led to development of knee joint damage associated with changes in the metabolic profile in rats. Vit D supplementation dramatically improved knee joint damage, obesity insulin resistance, dyslipidemia and inflammation systemically and locally while controlling gut dysbiosis by antibiotics did not improve obesity, local inflammation and knee damage but improved the other parameters less than Vit D.
\end{abstract}

Key Words: Inflammation - Metabolic syndrome - Obesity Oxidative stress.

\section{Introduction}

OSTEOARTHRITIS (OA) is a common chronic joint disorder and one of the causes of disability [1], with a multifactorial etiology including post-

Correspondence to: Dr. Randa S. Gomaa,

E-Mail: salah randah@hotmail.com traumatic, ageing, genetic [2]. Metabolic OA is a newly defined phenotype associated with metabolic syndrome (MetS) [3]. MetS associates with a state of chronic low-grade inflammation, through elevated levels of cytokines, acute-phase inflammatory components as complements and $\mathrm{C}$ reactive protein (CRP) and other mediators has been implicated in the pathogenesis of OA [4].

It was reported that metabolic syndrome is accompanied with changes in gut microbiota [5] All metazoan, from invertebrates to vertebrates, has intestinal microbiota that plays a key role in host metabolism, immune function, nutrition [6] Gut microbial dysbiosis is considered one of the pivotal risk factors for obesity, atherosclerosis, cardiovascular diseases, type 2 diabetes (T2DM), and MetS [7]. The association of the gut microbiome with osteoarthritic pain and severity in the knee was recently suggested indicating that controlling microbiome is a possible therapeutic target for osteoarthritis-related knee pain [8]. The intestinal microbiota is strictly associated with the pathogenesis of numerous disorders and there is emerging evidence supports the hypothesis that the gut microbiome could be possible triggering factors for metabolic OA [9].

The main function of vitamin $\mathrm{D}$ is regulation of bone metabolism and calcium homeostasis via the nuclear receptors named vitamin $D$ receptors (VDRs). Thus, inadequate vitamin D status is thought to affect the pathophysiology and progression of OA [10].

Furthermore, Vitamin D is believed to have effects on inflammation, alters cytokine synthesis and has positive effects on muscle strength [11].

Results from human studies had controversial findings as three randomized controlled trials 
(RCTs) found an insignificant role of vitamin D supplementation on cartilage volume or pain in knee OA [12-14] while one RCT showed a significant decrease in OA pain, and an increase in knee function [15]. A small non-controlled study found a significant increase in muscle strength after two months of vitamin D supplementation to patients with knee OA [16]. In a recent trial, significantly improved structural and functional outcomes were found in patients with knee OA who maintained sufficient plasma vitamin D compared to those insufficient [17]

On basis of these data, we suppose that if we compare the effect of vit. D supplementation and gut microbiota suppression on the development of metabolic knee OA in diet-induced rat model of MetS; we could recommend new insights in controlling metabolic osteoarthritis. So, comparing the effect of vit. D supplementation and gut microbiota suppression on the development of metabolic knee OA in diet-induced rat model of MetS is the aim of the current study.

\section{Material and Methods}

A total number of 40 adult male Wistar rats aged between 10 and 12 weeks $(200 \pm 20 \mathrm{~g})$ were purchased from animal house of Faculty of Veterinary Medicine, Zagazig University, Egypt. All experimental procedures and protocols were following the guide for the care and use of laboratory animals (8th edition, National Academies Press) and have been reviewed and approved by Zagazig University institutional animal care unit committee (ZU-IACUC; Sharkia; Egypt) with approval number: ZU-IACUC/3/F/115/2019. Before starting the experiment, all animals subjected to 14 days for house acclimatization under conditions of controlled temperature $\left(24-26^{\circ} \mathrm{C}\right)$, humidity $(50-60 \%)$ and 12 hrs light-dark cycle. They were fed on a standard diet with free access to water.

The animals were randomly divided into 2 main groups: Control group $(\mathrm{n}=10)$ : Were fed standard rat chow which consisted of $25.8 \%$ protein, $62.8 \%$ carbohydrate, and $11.4 \%$ fat, and tap water and high carbohydrate high fat (HCHF) group $(n=30)$ : The rats fed high carbohydrate high fat (HCHF) diet for 12 weeks, $(1 \mathrm{~kg})$ contained $375 \mathrm{~g}$ of sweetened condensed milk, $200 \mathrm{~g}$ of ghee, $175 \mathrm{~g}$ of fructose, $155 \mathrm{~g}$ of powdered rat food, $25 \mathrm{~g}$ of Hubble Mendel and Wakeman salt mixture and $50 \mathrm{~mL}$ of water. The drinking water was supplemented with $25 \%$ fructose [18]. HCHF animals were subdivided into three subgroups, 10 rats each: HCHF (positive control): Rats were fed HCHF diet, HCHF+D: Rats were fed HCHF diet with vit D3 supplementation and $\mathrm{HCHF}+\mathrm{AB}$ : Rats were fed HCHF diet receiving broad spectrum antibiotics in drinking water. The experiment lasts for 12 weeks after acclimatization of the rats to the experimental conditions. Both food formulae were obtained from Faculty of Agriculture, Zagazig University, Egypt.

\section{Vitamin D3 supplementation:}

Oral vitamin D3 (vidrop) (cholecalciferol) (Medical union pharmaceuticals, Abu-Sultan, Ismailia, Egypt) was diluted in corn oil and then given orally by gavage daily $(500 \mathrm{IU} / \mathrm{Kg} /$ day $)$ for a total duration of 12 weeks [19]. At the same time, rats in groups; control, $\mathrm{HCHF}, \mathrm{I} \mathrm{HCHF}+\mathrm{AB}$ were given oral corn oil by gavage.

\section{Broad-spectrum antibiotics regimen:}

Rats received antibiotics in drinking water composed of Vancomycin + metronidazole 0.5$1.0 \mathrm{~g} / \mathrm{L}$ each for a total duration of 12 weeks $[\mathbf{2 0 , 2 1}]$

\section{Blood sample collection:}

The rats were sacrificed after 12 hours of fasting under anesthesia (chloral hydrate) inhalation. Blood samples were obtained by exsanguination at the time of scarification, collected and allowed to clot for 2 hours at room temperature before centrifugation. Sera were stored at $-20^{\circ} \mathrm{C}$ until analysis. Repeated freezing and thawing was avoided.

\section{Determination of metabolic parameters:}

Body mass index (BMI) was calculated for each animal at the end of the experiment by the equation: BMI $\left(\mathrm{gm} / \mathrm{cm}^{2}\right)=$ Body weight $/$ length ${ }^{2}$ (nose to anus length) this index can be used as an indicator of obesity where the cutoff value of obesity BMI is more than $0.68 \mathrm{gm} / \mathrm{cm}^{2}$ [22]. The sera were examined for level of insulin by ELISA kits (Bio Basic INC, NY, USA) and glucose by enzymatic colorimetric assay using commercial kits (Cayman chemicals, Michigan, USA). The homeostatic model assessment for insulin resistance (HOMA-IR) was calculated from the formula: [HOMA-IR = Insulin (mIU/L) x glucose $(\mathrm{mg} / \mathrm{dL}) /$ 405] [23] . For lipid profile assessment, total cholestero 1 (TC), HDL-cholesterol, LDL-cholesterol and triglycerides (TG) using enzymatic colorimetric assays using commercial kits (Calgary Lab Service, Calgary, Canada) were examined.

\section{Determination of inflammatory cytokines:}

By using ELISA kits; serum and synovial fluid pro inflammatory cytokines; interleukin-6 (IL-6) (Ray Biotech Inc. USA), USA) \& tumor necrosis factor $\alpha(\mathrm{TNF}-\alpha)$ (Koma Biotech. Inc. Korea) and anti-inflammatory cytokine interleukin-10 (IL-10) 
(DRG International Inc., were determined as the recommendations of the manufacturers.

Real time-Polymerase chain reaction (RT-PCR) measurement of tissue degenerative enzymes gene expression:

Right knee joints and subchondral bones were dissected, rinsed in ice-cold saline and were frozen at $-80^{\circ} \mathrm{C}$ for subsequent biochemical measurements of myeloperoxidase (MPO), matrix metalloproteinase2 (MMP2), and tissue inhibitor metalloproteinase2 (TIMP2) by RT-PCR technique [24]
Total RNA was extracted from joint tissue samples using SV Total RNA isolation system (Promega, Madison, WI, USA) which provides fast and simple technique for isolation of RNA.SV mean (spin or vacuum) purification protocol. The extracted RNA was reverse transcribed into cDNA and amplified by PCR using RT-PCR kit (Stratagene, USA). The relative gene expression ratio is calculated from the real-time PCR using the $2-\Delta \Delta \mathrm{Ct}$ method and glyceraldehyde-3-phosphate dehydrogenase (GAP$\mathrm{DH})$ as reference gene. The sets of primers used were listed in Table (1).

Table (1): Primer sequences.

\begin{tabular}{lll}
\hline Gene & \multicolumn{1}{c}{ Forward } & Reverse \\
\hline MMP2 & 5'-TATAGAACTCCAACCACAC-3' & 5'-CCGTAGAAGGTCCTCGTC-3' \\
TIMP2 & 5'-CGCTACCAACGGTGGAAGRC-3' & 5'-CAAGCTCCCCCTCTTTTCA-3' \\
MPO & 5'-ACCTACCCCAGTACCGATCC-3' & 5'-AACTCTCCAGCTGGCAAAAA-3' \\
GAPDH & 5'-ATGACTCTACCCACGGCAAG-3' & 5'-CTGGAAGATGGTGATGGGTT-3' \\
\hline Myeloperoxidase = MPO. & Tissue inhibitor metalloproteinase2 = TIMP2. \\
Matrix metalloproteinase2 = MMP2. & Glyceraldehyde-3-phosphate dehydrogenase = GAPDH
\end{tabular}

Knee joint histopathology: The left knee was harvested by cutting the femur and tibia/fibula $2 \mathrm{~cm}$ above and below the joint line, respectively. Muscles were removed and joints were fixed kept in $10 \%$ buffered formalin and $1 \%$ HNO3 for 1 day or more till they become soft, rinsed with runny water then put in alcohol series (different concentrations of alcohol) in order to remove all water from tissues before putting in paraffin, and were kept in xylene paraffin. Serial sagittal plane sections of 10 mickness were obtained, stained with hematoxylin and eosin ( $\mathrm{H} \& \mathrm{E})$ for histopathological examination. All histological sections were scored using a Modified Mankin Histology Scoring System [25]

Statistical analysis: The results are presented as descriptive statistics (mean \pm standard deviation). Statistical analysis was performed using the Statistical Package for Social Science (SPSS) version 25 (SPSS, Inc., IBM Company, Chicago, IL, USA). The normal distribution of data from each group was confirmed using the Kolmogorov-Smirnov normality test. Since the test indicated that variables followed normal distribution, comparisons among the experimental groups were analyzed by oneway analysis of variance (ANOVA) followed by least significance differences (LSD) test to evaluate statistical difference between two groups. $p$-value $<0.05$ was considered to be statistically significant.

\section{Results}

Metabolic parameters: There was significant increase in insulin, glucose, HOMA-IR, in HCHF and $\mathrm{HCHF}+\mathrm{AB}$ group in comparison to control one $(p<0.001)$ with insignificant change in these parameters in $\mathrm{HCHF}+\mathrm{D}$ when compared with control group ( $p=0.75,0.54,0.173$ respectively) while there was significant increase in BMI, TC, TG, LDL-C with decrease in HDL-C in all groups in comparison to control one $(p<0.001)$. Both Vit $\mathrm{D}$ and Antibiotic administration induced significant decrease in all parameters $(p<0.001)$ and significant increase in HDL-C ( $p<0.001, p=0.002$ respectively) in comparison to $\mathrm{HCHF}$ group except BMI which showed insignificant change in $\mathrm{HCHF}+\mathrm{AB}$ group compared with HCHF group $(p=0.119)$. There was significant increase in insulin, glucose, HOMAIR $(p<0.001)$, BMI $(p=0.016)$, TC $(p=0.007)$, TG $(p=0.002)$, LDL-C $(p=0.001)$ and significant decrease in HDL-C $(p=0.025)$ in $\mathrm{HCHF}+\mathrm{AB}$ when compared with $\mathrm{HCHF}+\mathrm{D}$ (Table 2).

Serum and synovial inflammatory cytokines: There was significant increase in serum and synovial levels IL-6 and TNF- $\alpha$ with decrease in IL10 in all groups in comparison to control one $(p<0.001)$. There was significant decrease in serum and synovial levels IL- 6 and TNF- $\alpha$ with significant increase in IL-10 in HCHF+D group in comparison to HCHF one $(p<0.001)$. Antibiotic administration induced the same effect like Vit D on the serum cytokines $(p<0.001)$ while produced insignificant changes in synovial IL-6, TNF- $\alpha$ and IL-10 in comparison to HCHF group ( $p=0.064,0.089,0.112$ respectively). There was significant increase in serum and synovial levels IL- 6 and TNF- $\alpha$ with decrease in IL-10 in $\mathrm{HCHF}+\mathrm{AB}$ group in comparison to $\mathrm{HCHF}+\mathrm{D}$ group $(p<0.001)$ (Table 3$)$. 


\section{Tissue degenerative enzyme gene expression:}

There was significant increase in tissue MPO and MMP2 with decrease in TIMP2 in all groups in comparison to control animals $(p<0.001)$. There was significant decrease in tissue MPO and MMP2 with significant increase in TIMP2 in $\mathrm{HCHF}+\mathrm{D}$ group in comparison to $\mathrm{HCHF}$ one $(p<0.001)$.
Antibiotic administration produced insignificant changes in tissue MPO, MMP2 and TIMP2 in comparison to HCHF group ( $p=0.132,0.86,0.173$ respectively). There was significant increase in tissue MPO and MMP2 with decrease in TIMP2 in $\mathrm{HCHF}+\mathrm{AB}$ group in comparison to $\mathrm{HCHF}+\mathrm{D}$ group $(p<0.001)$ (Table 4$)$.

Table (2): Effect of vit D3 supplementation and antibiotic administration to HCHF fed rats on BMI, Glucose metabolism and lipid profile parameters.

\begin{tabular}{|c|c|c|c|c|}
\hline & Control & $\mathrm{HCHF}$ & $\mathrm{HCHF}+\mathrm{D}$ & $\mathrm{HCHF}+\mathrm{AB}$ \\
\hline BMI $\left(\mathrm{gm} / \mathrm{cm}^{2}\right)$ & $0.41 \pm 0.036$ & $0.76 \pm 0.027 \mathbf{a}$ & $0.71 \pm 0.022^{\mathbf{a}^{\prime} \mathbf{b}}$ & $0.74 \pm 0.0355^{\mathbf{a} c}$ \\
\hline Insulin (mIU/L) & $18.8 \pm 2.5$ & $36.1 \pm 2.3 \mathbf{a}$ & $20.9 \pm 1.8 \mathbf{b}$ & $30.1 \pm 3.3$ a,b,c \\
\hline Glucose (mg/dL) & $96.8 \pm 6.4$ & $136.9 \pm 5.3 \mathbf{a}$ & $102.3 \pm 6.4 \mathbf{b}$ & $118.1 \pm 5.04^{\mathbf{a}^{\prime} \mathbf{b}^{\prime} \mathbf{c}}$ \\
\hline HOMA-IR & $4.6 \pm 0.4$ & $12.5 \pm 2.3 \mathrm{a}$ & $5.4 \pm 0.7 \mathbf{b}$ & $8.1 \pm 0.9^{\mathbf{a}} \mathbf{b}^{\prime} \mathbf{c}$ \\
\hline $\mathrm{TC}(\mathrm{mg} / \mathrm{dL})$ & $107.2 \pm 7.3$ & $157.1 \pm 7.9$ & $119.3 \pm 5.03 \mathbf{a}^{\mathbf{a}} \mathbf{b}$ & $128.3 \pm 7.3^{\mathbf{a} \mathbf{a}^{\prime} \mathbf{c}}$ \\
\hline TG (mg/dL) & $66.8 \pm 10.4$ & $124.6 \pm 7.1 \mathrm{a}$ & $86.8 \pm 11.7 \mathbf{a} \cdot \mathbf{b}$ & $102.5 \pm 11.3 \mathbf{a}, \mathbf{b}, \mathbf{c}$ \\
\hline HDL-C (mg/dL) & $54.8 \pm 9.1$ & $26.7 \pm 6.7 \mathbf{a}$ & $43.2 \pm 4.5^{\mathbf{a}, \mathbf{b}}$ & $36.3 \pm 5.03^{\mathbf{a}^{\prime} \mathbf{b}} \mathbf{c}$ \\
\hline LDL-C (mg/dL) & $42.9 \pm 4.9$ & $112.5 \pm 7.5 \mathrm{a}$ & $71.8 \pm 6.9^{\mathbf{a}^{\prime} \mathbf{b}}$ & $82.7 \pm 7.1$ a,b,c \\
\hline
\end{tabular}

$\mathrm{n}=10$ in each group.

Data are represented as mean $\pm \mathrm{SD}$.

BMI : Body mass index.

HDL-C : High-density lipoprotein-cholesterol.

$\mathrm{HCHF}$ : High carbohydrate high fat.

$\mathrm{HCHF}+\mathrm{AB}$ : High carbohydrate high fat+ antibiotic.

$\mathrm{HCHF}+\mathrm{D}$ : High carbohydrate high fat + vit D.

HOMA-IR: Homeostasis model assessment-insulin resistance.

LDL-C : Low-density lipoprotein-cholesterol.

TC: Total cholesterol.

TG: Triglyceride. Significance $(p<0.05)$ :

(a) Significant when compared with control group.

(b) Significant when compared with HCHF fed group.

(c) Significant when compared with $\mathrm{HCHF}+\mathrm{D}$ group.

Table (3): Effect of vit D3 supplementation and antibiotic administration to HCHF fed rats on serum and synovial fluid inflammatory cytokines (IL-6, TNF- $\alpha$ \& IL-10 ) levels.

\begin{tabular}{|c|c|c|c|c|}
\hline & Control & $\mathrm{HCHF}$ & $\mathrm{HCHF}+\mathrm{D}$ & $\mathrm{HCHF}+\mathrm{AB}$ \\
\hline \multicolumn{5}{|l|}{ Serum: } \\
\hline IL-6 (pg/ml) & $10.8 \pm 2.9$ & $43.9 \pm 4.4 \mathbf{a}$ & $20.3 \pm 3.4^{\mathbf{a}} \mathbf{b}$ & $33.6 \pm 4.4^{\mathbf{a}^{\prime} \mathbf{b}^{\prime} \mathbf{c}}$ \\
\hline $\mathrm{TNF}-\alpha(\mathrm{pg} / \mathrm{ml})$ & $15.3 \pm 3.6$ & $64.2 \pm 6.6 \mathbf{a}$ & $30.5 \pm 5.6^{\mathbf{a}} \mathbf{b}$ & $42.8 \pm 4.9 \mathbf{a}^{\prime} \mathbf{b}^{\prime} \mathbf{c}$ \\
\hline IL-10 (pg/ml) & $54.1 \pm 5.01$ & $17.9 \pm 5.07 \mathbf{a}$ & $40 \pm 6.03 \mathbf{a}^{\mathbf{a}} \mathbf{b}$ & $30.2 \pm 3.7^{\mathbf{a}} \mathbf{b}{ }^{\prime} \mathbf{c}$ \\
\hline \multicolumn{5}{|l|}{ Synovial fluid: } \\
\hline IL-6 (pg/ml) & $596 \pm 55$ & $2074.5 \pm 109 a$ & $970.7 \pm 87 \mathbf{a} \cdot \mathbf{b}$ & $1994 \pm 119 \mathbf{a , c}$ \\
\hline $\mathrm{TNF}-\alpha(\mathrm{pg} / \mathrm{ml})$ & $91.6 \pm 6.4$ & $240.3 \pm 11.5 \mathbf{a}$ & $137.9 \pm 6.8^{\mathbf{a} \cdot \mathbf{b}}$ & $232.5 \pm 13.4 \mathbf{a}^{\prime} \mathbf{c}$ \\
\hline IL-10 (pg/ml) & $928 \pm 27.8$ & $280 \pm 11.7 \mathbf{a}$ & $735 \pm 34.8^{\mathbf{a}^{\prime} \mathbf{b}}$ & $298 \pm 18.3^{\mathbf{a} c}$ \\
\hline \multicolumn{5}{|c|}{$\begin{array}{l}-\mathrm{n}=(10) \text { in each group Data are represented as } \\
\text { mean } \pm \text { standard deviation. } \\
\text { IL- } 6: \text { Inerlukin- } 6 \text {. } \\
\text { IL- } 10: \text { Inerlukin- } 10 \text {. } \\
\text { TNF- } \alpha \text { : Tumor necrotic factor- } \alpha \text {. }\end{array}$} \\
\hline \multicolumn{5}{|c|}{$\begin{array}{l}\text { Table (4): Effect of vit D3 supplementation and antibiotic administration to HCHF fed rats on knee joint } \\
\text { tissue degenerative enzyme gene expressions with (GAPDH) as reference gene. }\end{array}$} \\
\hline & Control & $\mathrm{HCHF}$ & $\mathrm{HCHF}+\mathrm{D}$ & $\mathrm{HCHF}+\mathrm{AB}$ \\
\hline MPO/GADPH & $0.1 \pm 0.01$ & $1.1 \pm 0.08 \mathbf{a}$ & $0.5 \pm 0.06^{\mathbf{a}} \mathbf{b}$ & $1 \pm 0.08 \mathbf{a}^{\prime} \mathbf{c}$ \\
\hline MMP2/GADPH & $1.7 \pm 0.1$ & $10.2 \pm 1.6 \mathbf{a}$ & $4.3 \pm 0.6^{\mathbf{a}^{\prime} \mathbf{b}}$ & $9.2 \pm 1.5 \mathbf{a}, \mathbf{c}$ \\
\hline TIMP2/GADPH & $26.3 \pm 2.2$ & $13.4 \pm 2.6 \mathbf{a}$ & $21.7 \pm 2.03^{\mathbf{a}} \mathbf{b}$ & $14.9 \pm 2.7 \mathbf{a}, \mathbf{c}$ \\
\hline
\end{tabular}

- $\mathrm{n}=(10)$ in each group Data are represented as mean \pm standard deviation.

MPO : Myeloperoxidase.

MMP2: Matrix metalloproteinase2.

TIMP2: Tissue inhibitor metalloproteinase2
Significance $(p<0.05)$ :

(a) Significant when compared with control group.

(b) Significant when compared with HCHF fed group.

(c) Significant when compared with $\mathrm{HCHF}+\mathrm{D}$ group. 


\section{Knee joint damage:}

There was significant increase in Modified Mankin scores in all groups in comparison to control animals $(p<0.001)$. There was significant decrease Modified Mankin in HCHF+D group in comparison to $\mathrm{HCHF}$ one $(p<0.001)$. Antibiotic

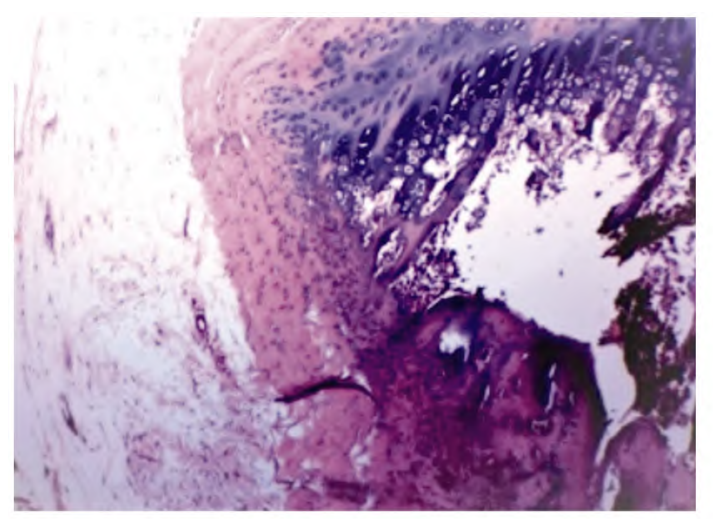

(A) Control

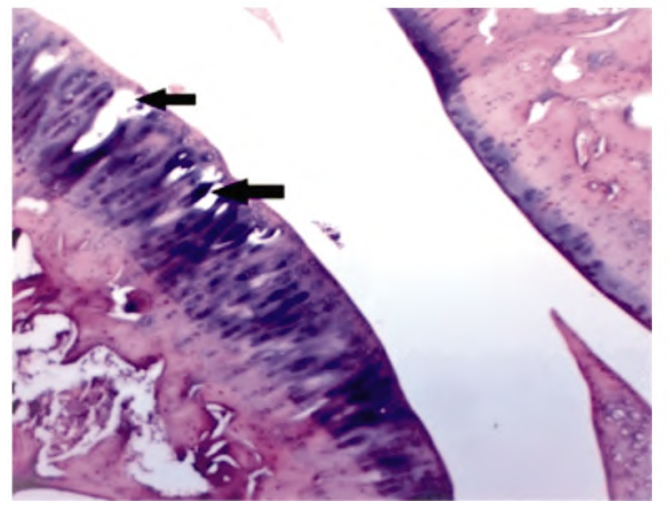

(C) $\mathrm{HCHF}+\mathrm{D}$ administration produced insignificant changes Modified Mankin scores in comparison to HCHF group ( $p=0.07)$. There was significant increase in Modified Mankin scores in $\mathrm{HCHF}+\mathrm{AB}$ group in comparison to $\mathrm{HCHF}+\mathrm{D}$ group $(p<0.001)$ (Fig. 1).

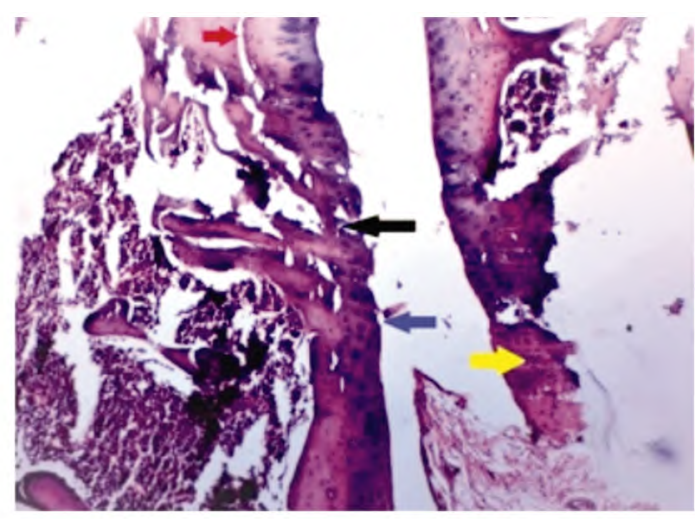

(B) $\mathrm{HCHF}$

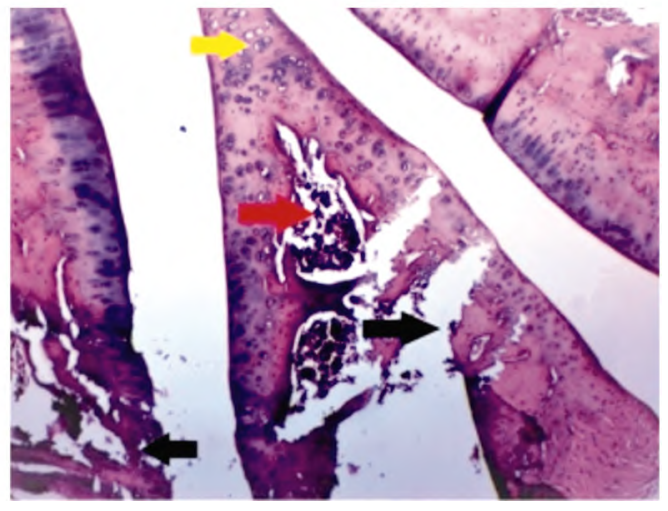

(D) $\mathrm{HCHF}+\mathrm{AB}$

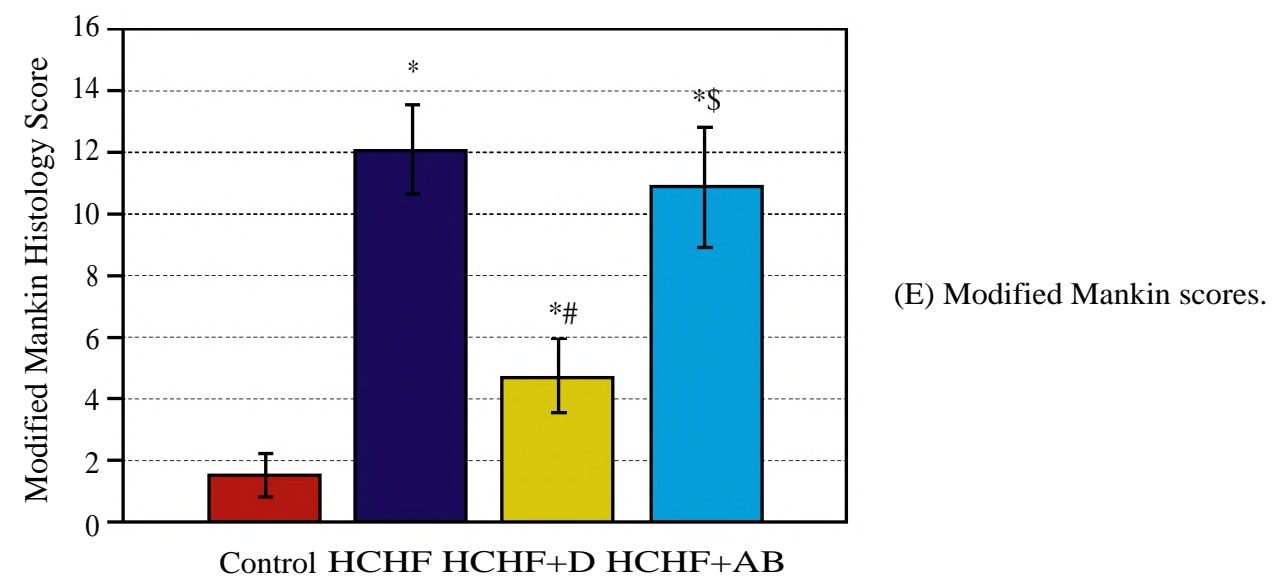

Fig. (1): Histology images taken at $x 200$, showing the normal features of the articular cartilage of the control group and the joint damage features in the other groups in the form of weak staining of chondrocytes (yellow arrow), fibrillation and fissuring of the cartilage (black arrow), vascularization into the articular cartilage (red arrow), and osteophyte formation (blue arrow). $\mathrm{HCHF}$, high carbohydrate high fat; $\mathrm{HCHF}+\mathrm{AB}$, high carbohydrate high fat + antibiotic; $\mathrm{HCHF}+\mathrm{D}$, high carbohydrate high fat + vit D. Modified Mankin scores: $\mathrm{n}=(10)$ in each group. Data are represented as mean \pm standard deviation. Significance $(p<0.05)$ : $(*)$ Significant when compared with control group, (\#) Significant when compared with HCHF fed group, (\$) significant when compared with $\mathrm{HCHF}+\mathrm{D}$ group. 


\section{Discussion}

In the present study, adult male rats on the HCHF diet showed increased BMI compared with normal chew fed rats and this obesity was associated with dyslipidemia, elevated insulin and glucose, levels with reduction in insulin sensitivity evidenced by increased HOMA-IR. These results come in agreement with Wong et al. [18] who demonstrated that MetS is successfully established in rats induced by the HCHF diet after 12 weeks. Other reviews discussed the various animal models of MetS [26,27].

The results of the current study revealed that a 12-week MetS induction period led to obesity, hyperglycemia, insulin resistance and altered lipid metabolism that associated with increased serum and synovial pro inflammatory and decreased antiinflammatory markers with development of histopathological OA-related changes in knee joints. These findings are supported by results of other researches that investigated the role of MetS in developing joint ostearthritis [28] or specifically knee osteoarthritis [29] in a rat model. There is a strong evidence that inflammation plays a fundamental role in osteoarthritis pathogenesis, by affecting chondrocyte catabolic responses that can be triggered within the joint either locally from tissue damage and stress responses or systemically from obesity-related inflammation that might enhance these local responses [30]. Many studies have demonstrated that adipose tissue-derived inflammatory mediators, hyperglycemia, insulin resistance, or dyslipidemia could affect the metabolism of the joint as for other organs [31,32]

TNF-a and IL-6 seem to be the main pro inflammatory cytokines and are critical mediator of the disturbed metabolism and enhanced catabolism of cartilage destruction in OA [33]. Moreover, Collins et al. [34] identified dysregulation of proinflammatory markers in serum and synovial fluid that may be involved in accelerated OA progression in rat model of MetS. IL-10 is an anti-inflammatory cytokine that has cartilage protective effect in the course of OA as it inhibits TNF a synthesis, increases proteoglycan synthesis, inhibits chondrocytes apoptosis, decrease metalloproteinases synthesis and secretion, and decreases level of PGE2. [35].

The present study showed remarkable increase in MPO and MMP2 along with TIMP2 decrease in $\mathrm{HCHF}$ rats that may be attributed to certain imbalance between these enzymes as MPO has been found to disrupt the physiological balance of
MMPs and functions of MMP inhibitors besides the negative correlation between MPO and both TIMP2 and IL-10 reflecting a high rate of turnover in articular cartilage [36]. It could be explained by that TNF-a stimulates chondrocytes to release several proteolytic enzymes, and can drive the catabolic process in OA leading to cartilage degradation [33].

Vit D administration in the current study led to improved obesity, hyperglycemia, insulin resistance, altered lipid metabolism, disturbed serum and synovial inflammatory markers and the structural changes in knee joints produced by HCHF diet. These results come in agree with the results of Mostafa et al. [37] who demonstrated that vitamin D supplementation ameliorated hyperinsulinemia, insulin resistance, obesity as well as dyslipidemia but not hyperglycemia in rat model of MetS. In addition, vit.D administration reduced weight and food intake, inflammation and several oxidative stress markers in adipose tissue of high-fat diet fed rats [38]. Human and experimental data indicate a role for vitamin $\mathrm{D}$ deficiency in the development of type-2 diabetes [39], Rheumatoid Arthritis [40] and osteoarthritis [41].

In contrary, a human study demonstrated positive relationship of Vit D levels with HOMA-IR and inverse correlation with HDL but didn't found association between Vit D levels and other metabolic syndrome components [42]. Other human study founded no significant relationships between vitamin D3 levels and MetS parameters as triglycerides, LDL, HDL, and total cholesterol [43]. Several human studies have examined the relationship between vit. D supplementation and serum levels cytokines. Barker et al. [44] showed a positive relationship with IL-10 while Peterson and Heffernan [45] reported a significant inverse relationship with serum TNF-a but no relationship with IL-6, or IL-10. Another study founded no significant changes in serum levels of IL-10, IL-6, or TNFa [46]

Suppressing gut microbiota led to improved hyperglycemia, insulin resistance, altered lipid metabolism, disturbed serum but not synovial inflammatory markers while failed to modify obesity or the structural changes in knee joints produced by HCHF diet. Vit. D showed superior results when compared with controlling gut dysbiosis. Many studies suggested that a high-fat diet can lead to gut microbiota dysbiosis that increased gut permeability and metabolic endotoxemia. This in turn contributes to low-grade inflammation and insulin resistance, obesity and diabetes [47]. 
In our study, the antibiotics were used to deplete the gut microbiota of rats as vancomycin, which is a Gram+-targeting and metronidazole encompasses various protozoans and most anaerobic bacteria to assess the effect microbiota depletion on MetS associated OA. Although many studies examined phenotypic differences after antibiotics treatment, some studies have assessed how regimens affect commensal populations at other sites [21].

Our results supported by findings of Rios et al., who postulated that controlling gut microbiota dysbiosis by prebiotic fiber supplementation improved insulin resistance, dyslipidemia observed in this rat model of obesity. In contract, prebiotic fiber supplementation completely prevented knee joint damage that could not be achieved by using antibiotics in our study [29]

Controlling gut dysbiosis by antibiotic in the current study did not improve obesity that supported by results of other studies used antibiotics in human [48] and mice [49]. This obesity could explain unimproved knee arthritis in spite of improved insulin resistance, dyslipidemia and systemic inflammatory cytokines in antibiotic treated rats in the current study.

In conclusion, HCHF diet led to development of knee joint damage associated with changes in the metabolic profile in rats. Vit D supplementation dramatically improved knee joint damage, obesity insulin resistance, dyslipidemia and inflammation systemically and locally while controlling gut dysbiosis by antibiotics did not improve obesity, local inflammation and knee damage but improved the other parameters less than Vit D. Further investigation of controlling gut microbiota by other like prebiotic fibers or probiotic supplements on metabolic OA is recommended.

\section{Acknowledgements:}

The authors acknowledge Assis. Prof. Hayam Elsaid Rashed, Pathology Department, Faculty of Medicine, Zagazig University for histopathological assessment.

\section{Conflicts of interest:}

All authors have no conflicts of interest.

\section{Financial support:}

Nil.

\section{References}

1- KUYINU E.L., NARAYANAN G., NAIR L.S. and LAURENCIN C.T.: Animal models of osteoarthritis: Classifi- cation, update, and measurement of outcomes. J. Orthop. Surg. Res., 11: 19-45, 2016.

2- BLAGOJEVIC M., JINKS C., JEFFERY A. and JORDAN K.P.: Risk factors for onset of osteoarthritis of the knee in older adults: A systematic review and meta-analysis. Osteoarthritis Cartilage, 18: 24-33, 2010.

3- SELLAM J. and BERENBAUM F.: Is osteoarthritis a metabolic disease? Joint Bone Spine, 80: 568-573, 2013.

4- BERENBAUM F., GRIFFIN T.M. and LIU-BRYAN R.: Review: Metabolic Regulation of Inflammation in Osteoarthritis. Arthritis Rheumatol., 69: 9-21, 2017.

5- TILG H and KASER A.: Gut microbiome, obesity, and metabolic dysfunction. J. Clin. Invest., 121: 2126-2132, 2011.

6- LEE W.J. and HASE K.: Gut microbiota-generated metabolites in animal health and disease. Nature Chemical Biology, 10: 416-424, 2014.

7- MOHAJERI M.H., La FATA G., STEINERT R.E. and WEBER P.: Relationship between the gut microbiome and brain function. Nutrition Reviews,76: 481-496, 2018.

8- BOER C.G., RADJABZADEH D., MEDINA-GOMEZ C., GARMAEVA S., SCHIPHOF D., ARP P., KOET T., KURILSHIKOV A., FU J., IKRAM M.A., BIERMAZEINSTRA S., UITTERLINDEN A.G., KRAAIJ R. ZHERNAKOVA A. and VAN MEURS J.B.J.: Intestinal microbiome composition and its relation to joint pain and inflammation. Nat. Commun., 10: 4881-4889, 2019.

9- SZYCHLINSKA M.A., Di ROSA M., CASTORINA A., MOBASHERI A. and Musumeci G.: A correlation between intestinal microbiota dysbiosis and osteoarthritis. Heliyon, 5: e01134-1160, 2019.

10- MABEY T and HONSAWEK S.: Role of vitamin D in osteoarthritis: Molecular, cellular, and clinical perspectives. Int. J. Endocrinol., 2015: 383918-38331, 2015.

11- TOMLINSON P.B., JOSEPH C. and ANGIOI M.: Effects of vitamin D supplementation on upper and lower body muscle strength levels in healthy individuals. A systematic review with meta-analysis. J. Sci. Med. Sport, 18: 575580, 2015.

12- McALINDON T., LaVALLEY M., SCHNEIDER E., NUITE M., LEE J.Y., PRICE L.L., LO G. and DAWSONHUGHES B.: Effect of vitamin D supplementation on progression of knee pain and cartilage volume loss in patients with symptomatic osteoarthritis: A randomized controlled trial. JAMA, 309: 155-162, 2013.

13- JIN X., JONES G., CICUTTINI F., WLUKA A., ZHU Z., HAN W., ANTONY B., WANG X., WINZENBERG T., BLIZZARD L. and DING C.: Effect of vitamin D supplementation on tibial cartilage volume and knee pain among patients with symptomatic knee osteoarthritis a randomized clinical trial. JAMA, 315: 1005-1013, 2016.

14- ARDEN N.K., CRO S., SHEARD S., DORÉ C.J., BARA A., TEBBS S.A., HUNTER D.J., JAMES S., COOPER C., O'NEILL T.W., MACGREGOR A., BIRRELL F. and KEEN R.: The effect of vitamin D supplementation on knee osteoarthritis, the VIDEO study: A randomised controlled trial. Osteoarthritis Cartilage, 24: 1858-1866, 2016.

15- SANGHI D., MISHRA A., SHARMA A.C., SINGH A., NATU S.M., AGARWAL S. and SRIVASTAVA R.N.: 
Does vitamin D improve osteoarthritis of the knee: A randomized controlled pilot trial. Clin. Orthop. Relat. Res., 471: 3556-3562, 2013.

16- HEIDARI B., JAVADIAN Y., BABAEI M. and YOUSEFGHAHARI B.: Restorative effect of vitamin D deficiency on knee pain and quadriceps muscle strength in knee osteoarthritis. Acta. Medica Iranica, 53: 466-470, 2015.

17- ZHENG S., JIN X., CICUTTINI F., WANG X., ZHU Z., WLUKA A., HAN W., WINZENBERG T., ANTONY B., AITKEN D., BLIZZARD L., JONES G. and DING C.: Maintaining vitamin D sufficiency is associated with improved structural and symptomatic outcomes in knee osteoarthritis. Am. J. Med., 130: 1211-1218, 2017.

18- WONG S.K., CHIN K.Y., SUHAIMI F.H., AHMAD F. and IMA-NIRWANA S.: The effects of a modified highcarbohydrate high-fat diet on metabolic syndrome parameters in male rats. Exp. Clin. Endocrinol. Diabetes, 126: 205-212, 2017.

19- FARHANGI M.A., NAMENI G., HAJILUIAN G. and MESGARI-ABBASI M.: Cardiac tissue oxidative stress and inflammation after vitamin D administrations in high fat- diet induced obese rats. BMC Cardiovasc. Disord., 17: 161-168, 2017.

20- ATARASHI K., NISHIMURA J., SHIMA T., UMESAKI Y., YAMAMOTO M., ONOUE M., YAGITA H., ISHII N., EVANS R., HONDA K. and TAKEDA K.: ATP drives lamina propria TH17 cell differentiation. Nature, 455: 808-812, 2008.

21- KENNEDY E.A., KING K.Y. and BALDRIDGE M.T.: Mouse Microbiota Models: Comparing Germ-Free Mice and Antibiotics Treatment as Tools for Modifying Gut Bacteria. Front. Physiol., 9: 1534-1549, 2018.

22- NOVELLI E.L., DINIZ Y.S., GALHARDI C.M., EBAID G.M., RODRIGUES H.G., MANI F., FERNANDES A.A., CICOGNA A.C. and NOVELLI FILHO J.L.: Anthropometrical parameters and markers of obesity in rats. Lab. Anim., 41: 111-119, 2007.

23- SINGH B and SAXENA A.: Surrogate markers of insulin resistance: A review. World J. Diabetes, 1: 36-47, 2010.

24- PFAFFL M.W.: A new mathematical model for relative quantification in real-time RT-PCR. Nucleic acids research, 29: e45-e50, 2001.

25- MANKIN H.J., DORFMAN H., LIPPIELLO L. and ZARINS A.: Biochemical and metabolic abnormalities in articular cartilage from osteoarthritic human hips. II. Correlation of morphology with biochemical and metabolic data. J. Bone Joint Surg. Am., 53: 523-537, 1971.

26- WONG S.K., CHIN K.Y., SUHAIMI F.H., FAIRUS A. and Ima-Nirwana S. Animal models of metabolic syndrome: A review. Nutr Metab (Lond), 13: 65-76, 2016.

27- RAUT S.K. and BANDAWANE D.: A Systematic Review on Animal Models of Metabolic Syndrome. Int. J. Pharma. Res. Health Sci., 6: 2089-2098, 2018.

28- COLLINS K.H., HART D.A., SEERATTAN R.A., REIMER R.A. and HERZOG W.: High-fat/high-sucrose dietinduced obesity results in joint-specific evelopment of ostearthritis-like Degeneration in a rat model. Bone Joint Res., 7: 274-281, 2018.

29- RIOS J.L., BOMHOF M.R., REIMER R.A., HART D.A., COLLINS K.H. and HERZOG W.: Protective effect of prebiotic and exercise intervention on knee health in a rat model of diet-induced obesity. Sci. Rep., 9: 3893$3902,2019$.

30- SCANZELLO C.R.: Role of low-grade inflammation in osteoarthritis. Curr. Opin. Rheumatol., 29: 79-85, 2017.

31- COURTIES A., BERENBAUM F. and SELLAM J.: Metabolic syndrome-associated osteoarthritis. Curr. Opin. Rheumatol., 29: 214-22, 2017.

32- ZHAI G.: Alteration of Metabolic Pathways in Osteoarthritis. Metabolites, 9: 11-22, 2019.

33- KAPOOR M., MARTEL-PELLETIER J., LAJEUNESSE D., PELLETIER J.P. and FAHMI H.: Role of proinflammatory cytokines in the pathophysiology of osteoarthritis. Nat. Rev. Rheumatol., 7: 33-42, 2011.

34- COLLINS K.H., HART D.A., REIMER R.A., SEERATTAN R.A. and HERZOG W.: Response to diet-induced obesity produces time-dependent induction and progression of metabolic osteoarthritis in rat knees. J. Orthop. Res., 34: 1010-1018, 2016.

35- WOJDASIEWICZ P., PONIATOWSKI L.A. and SZUKIEWICZ D.: The role of inflammatory and antiinflammatory cytokines in the pathogenesis of osteoarthritis. Mediators Inflamm., 2014 :561459-561477, 2014.

36- ALAM M.R., JI J.R., KIM M.S. and KIM N. S.: Biomarkers for identifying the early phases of osteoarthritis secondary to medial patellar luxation in dogs. J. Vet. Sci., 12: 273 280, 2011.

37- MOSTAFA D.K., NASRA R.A., ZAHRAN N. and GHONEIM M.T.: Pleiotropic protective effects of Vitamin $\mathrm{D}$ against high fat diet-induced metabolic syndrome in rats: One for all. Eur. J. Pharmacol., 792: 38-47, 2016.

38- FARHANGI M.A., MESGARI-ABBASI M., HAJILUIAN G., NAMENI G. and SHAHABI P.: Adipose Tissue Inflammation and Oxidative Stress: The Ameliorative Effects of Vitamin D. Inflammation, 40: 1688-1697, 2017.

39- ISSA C.M.: Vitamin D and Type 2 Diabetes Mellitus. Adv. Exp. Med. Biol., 996: 193-205, 2017.

40- MERLINO L.A., CURTIS J., MIKULS T.R., CERHAN J.R., CRISWELL L.A., SAAG K.G. and Iowa Women's Health Study: Vitamin D intake is inversely associated with rheumatoid arthritis: Results from the Iowa Women's Health Study. Arthritis Rheum., 50: 72-77, 2004.

41- McALINDON T.E., FELSON D.T., ZHANG Y., HANNAN M.T., ALIABADI P., WEISSMAN B., RUSH D., WILSON P.W. and JACQUES P.: Relation of dietary intake and serum levels of vitamin $D$ to progression of osteoarthritis of the knee among participants in the Framingham Study. Ann. Intern. Med., 125: 353-359, 1996.

42- RUDVAN AL L.Ç, SÖNMEZER M.Ç., ÇIÇEK A.G., KESKIN M., EFE F.K. and ÇIMEN LM.: Evaluation of the relationship between vitamin D levels and metabolic syndrome components. Biomedical Research (India), 28: 8717-8722, 2017.

43- WIEDER-HUSZLA S., JURCZAK A., SZKUP M., BARCZAK K., DOLEGOWSKA B., SCHNEIDER-MATYKA D., OWSIANOWSKA J. and GROCHANS E.: Relationships between Vitamin D and Metabolic Syndrome. Int. J. Environ. Res. Public Health, 16: 175-186, 2019. 
44- BARKER T., ROGERS V.E., LEVY M., TEMPLETON J., GOLDFINE H., SCHNEIDER E.D., DIXON B.M., HENRIKSEN V.T. and WEAVER L.K.: Supplemental vitamin $\mathrm{D}$ increases serum cytokines in those with initially low 25-hydroxyvitamin D: A randomized, double blind, placebo-controlled study. Cytokine, 71: 132-138, 2015.

45- PETERSON C.A. and HEFFERNAN M.E.: Serum tumor necrosis factor-alpha concentrations are negatively correlated with serum $25(\mathrm{OH}) \mathrm{D}$ concentrations in healthy women. J. Inflamm (Lond), 5: 10-18, 2008.

46- SUN X., CAO Z.B., ZHANG Y., ISHIMI Y., TABATA I. and HIGUCHI M.: Association between serum 25hydroxyvitamin D and inflammatory cytokines in healthy adults. Nutrients, 6: 221-230, 2014.

47- WEN L. and DUFFY A.: Factors Influencing the Gut Microbiota, Inflammation, and Type 2 Diabetes. J. Nutr., 147: 1468S-1475S, 2017.
48- REIJNDERS D., GOOSSENS G.H., HERMES G.D.A., NEIS E.P.J.G., VAN DER BEEK C.M., MOST J., HOLST J.J., LENAERTS K., KOOTTE R.S., NIEUWDORP M., GROEN A.K., OLDE DAMINK S.W., BOEKSCHOTEN M.V., SMIDT H., ZOETENDAL E.G., DEJONG C.H. and BLAAK E.E.: Effects of gut microbiota manipulation by antibiotics on host metabolism in obese humans: A randomized double-blind placebo-controlled trial. Cell Metab., 24: 63-74, 2016.

49- JANSSEN A.W.F., HOUBEN T., KATIRAEI S., DIJK W., BOUTENS L., VAN DER BOLT N., WANG Z., BROWN J.M., HAZEN S.L., MANDARD S., SHIRISVERDLOV R., KUIPERS F., WILLEMS VAN DIJK K., VERVOORT J., STIENSTRA R., HOOIVELD G.J.E.J. and KERSTEN S.: Modulation of the gut microbiota impacts nonalcoholic fatty liver disease: A potential role for bile acids. J. Lipid Res., 58: 1399-1416, 2017.

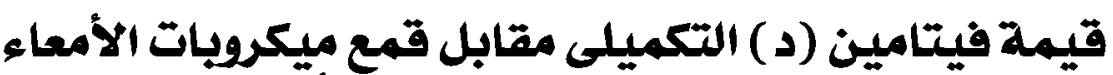

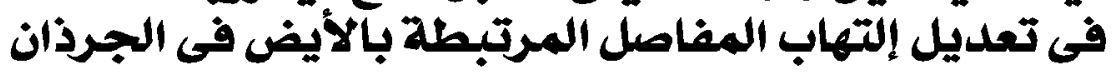

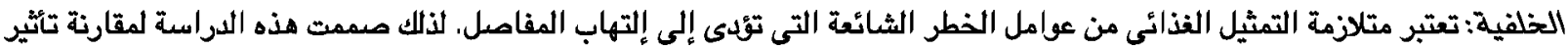 \\ مكملات فيتامين (د) بتأثير قمع ميكروبات الآمعاء الدقيقة على تطود إلتهاب المفاصل المئل المرتبط بالآيض للركبة في الجرذان. \\ مواد وطرق البحث: شملت الدراسة أربعين جرذان الذكود البالنة والتى تم تصنيفها إلى أربعة مجموعات متساوية كل منها عشرة جرذان: \\ - مجموعة ضابطة والتى تغذت على الغذاء المعتاد للجرذان. \\ - مجموعة حصلت على تغذية عالية الكريو هيدراث عالية الدهون. \\ - مجموعة حصلت على تغذية عالية الكريوهيدرات عالية الدهون بالإضافة إلى فيتا مين (د). \\ - مجموعة حصلت على تغذية عالية الكريوهيدرات عالية الدهون بالإضافة إلى المضادات الحيوية. \\ تم تقدير مؤشر كتلة الجسم وتحليل أمصال الدم لكل من قيمة الجلوكوف، الإنسو لين، الدهون الثلاثية، الكوليسترول الكلى، البروتين الدهنى

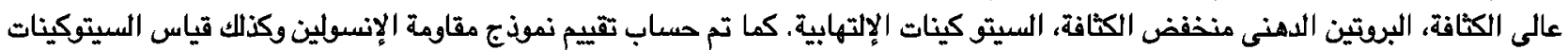 \\ الإلتهابية فى زلال الركبة. كما تم تقييم التعبير الجينى للانزيمات التنكسية وكذالك تم عمل دراسة ميكروسيكوبية للركبة.
}

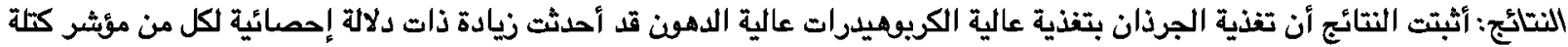

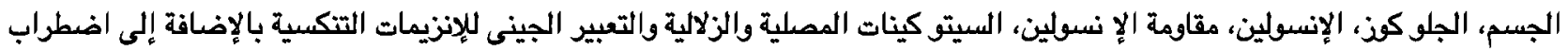

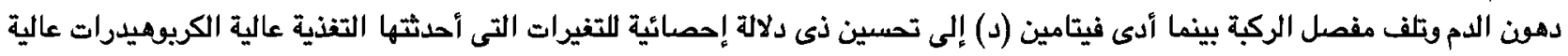

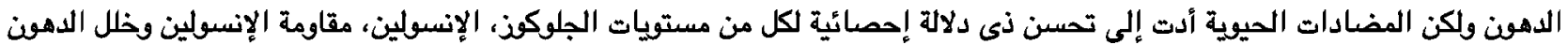
والسيتو كينات المصلية فقط.

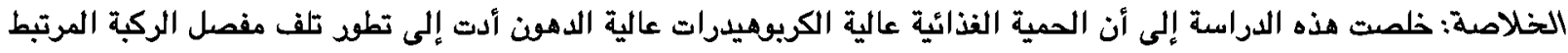

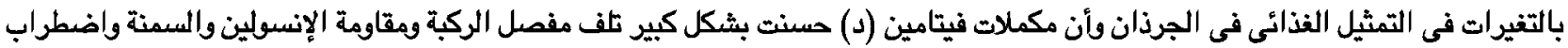

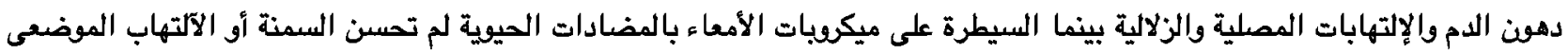
للركبة أوتلفها والكنها حسنت العوامل الأخرى ولكن بنسبة أقل من فيتامين (د). 